\title{
Thrombus aspiration in ST-segment elevation myocardial infarction before and after TASTE trial: experience from the Western Slavonia Primary Percutaneous Coronary Intervention Network
}

\section{Božo Vujeva, \\ Đeiti Prvulović, Krešimir Gabaldo, Ognjen Čančarević, Irzal Hadžibegović*}

General Hospital "Dr. Josip Benčević", Slavonski Brod, Croatia
RECEIVED:

February 9, 2016

ACCEPTED:

February 20, 2016

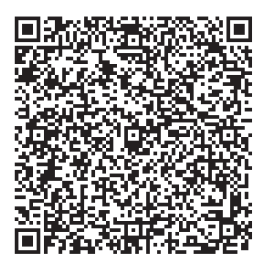

KEYWORDS: ST-segment elevation myocardial infarction, primary percutaneous coronary intervention, manual thrombectomy.

CITATION: Cardiol Croat. 2016;11(3-4):105. | DOI: http://dx.doi.org/10.15836/ccar2016.105

*ADDRESS FOR CORRESPONDENCE: Irzal Hadžibegović, Opća bolnica "Dr. Josip Benčević", Andrije Štampara 42, HR-35000 Slavonski Brod, Croatia. / Phone: +385-91-533-3091 / E-mail: irzalh@gmail.com

ORCID: Božo Vujeva, http://orcid.org/0000-0003-0490-3832 • Đeiti Prvulović, http://orcid.org/0000-0002-8041-1197 Krešimir Gabaldo, http://orcid.org/0000-0002-0116-5929 • Ognjen Čančarević, http://orcid.org/0000-0002-1285-8042 Irzal Hadžibegović, http://orcid.org/0000-0002-3768-9134

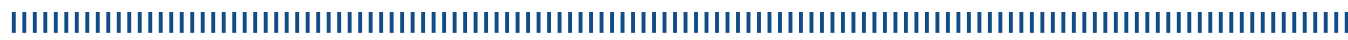

Background: Optimal results of primary percutaneous coronary intervention (PCI) in acute ST-segment elevation myocardial infarction (STEMI) are sometimes challenged by large thrombotic burden TAPAS (Thrombus Aspiration during Percutaneous coronary intervention in Acute myocardial Infarction Study) trial in 2008 first showed that thrombus aspiration in STEMI patients with large thrombotic burden improved overall survival after 1 year. ${ }^{1}$ Later on in 2013, Thrombus Aspiration in ST-Elevation Myocardial Infarction in Scandinavia (TASTE) trial, a prospective national registry showed no benefit of routine thrombectomy in STEMI. ${ }^{2} 2012$ European Society of Cardiology (ESC) Guidelines for the management of STEMI, that are currently available, gave a strong recommendation (IIaB) for manual thrombectomy in STEMI. ${ }^{3}$ However, that recommendation was downgraded to IIbA after TASTE trial in 2014 ESC Guidelines on myocardial revascularization. ${ }^{4}$ Here, we present the data on thrombus aspiration utilization within the Western Slavonia Primary PCI network, and compare the results between pre-TASTE and post-TASTE era.

Patients and Methods: Data on primary PCI techniques to achieve Thrombolysis in Myocardial Infarction (TIMI) 3 flow, on utilization of the glycoprotein IIb/IIIa inhibitors, and on clinical outcomes in STEMI were collected in 2012 and 2013, and compared to data from 2014 and 2015.

Results: In 2012 and 2013, out of 114 patients that underwent primary PCI in STEMI 32\% received thrombus aspiration, out of whom $61 \%$ had thrombus aspiration in the right coronary artery. Overall TIMI 3 rate was $88 \%$, and overall in-hospital mortality was 6.1\%. In 2014 and 2015 there were 253 patients with primary PCI in STEMI, with only $17 \%$ of thrombectomy cases (68\% of cases were done in the right coronary artery). Overall TIMI 3 rate was 91\%, and in-hospital mortality 5.9\%.

Conclusion: Thrombectomy penetration dropped significantly, together with the glycoprotein IIb/IIIa inhibitors use after publication of TASTE trial. Patients that received thrombectomy in 2014 and 2015 had mainly high thrombotic burden in the right coronary artery, or had embolic myocardial infarction. There were no changes in TIMI 3 achievement and in-hospital mortality. Manual thromboaspiration remains a useful tool only in selected population of patients with highly thrombotic lesions, aneurysmal coronary artery disease or embolic myocardial infarction.

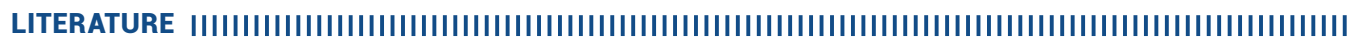

1. Vlaar PJ, Svilaas T, van der Horst IC, Diercks GF, Fokkema ML, de Smet BJ, et al. Cardiac death and reinfarction after 1 year in the Thrombus Aspiration during Percutaneous coronary intervention in Acute myocardial infarction Study (TAPAS): a 1-year follow-up study. Lancet. 2008;371(9628):1915-20. DOI: http://dx.doi.org/10.1016/S0140-6736(08)60833-8

2. Fröbert 0, Lagerqvist B, Olivecrona GK, Omerovic E, Gudnason T, Maeng M, et al; TASTE Trial. Thrombus aspiration during ST-segment elevation myocardial infarction. N Engl J Med. 2013 0ct 24;369(17):1587-97. DOI: http://dx.doi.org/10.1056/NEJMoa1308789

3. Task Force on the management of ST-segment elevation acute myocardial infarction of the European Society of Cardiology (ESC), Steg PG, James SK, Atar D, Badano LP, Blömstrom-Lundqvist C, Borger MA, et al. ESC Guidelines for the management of acute myocardial infarction in patients presenting with ST-segment elevation. Eur Heart J. 2012;33(20):2569-619. DOI: http://dx.doi.org/10.1093/eurheartj/ehs215

4. Authors/Task Force members, Windecker S, Kolh P, Alfonso F, Collet JP, Cremer J, Falk V, et al. 2014 ESC/EACTS Guidelines on myocardial revascularization: The Task Force on Myocardial Revascularization of the European Society of Cardiology (ESC) and the European Association for Cardio-Thoracic Surgery (EACTS)Developed with the special contribution of the European Association of Percutaneous Cardiovascular Interventions (EAPCI). Eur Heart J. 2014;35(37):2541-619. DOI: http://dx.doi.org/10.1093/eurheartj/ehu278 